\title{
Pluralism and its Perils: Navigating the Tension between Gay Rights and Religious Expression
}

Nan D. Hunter

Georgetown University Law Center, ndh5@law.georgetown.edu

This paper can be downloaded free of charge from:

https://scholarship.law.georgetown.edu/facpub/1469

http://ssrn.com/abstract=2579032

This open-access article is brought to you by the Georgetown Law Library. Posted with permission of the author. Follow this and additional works at: https://scholarship.law.georgetown.edu/facpub

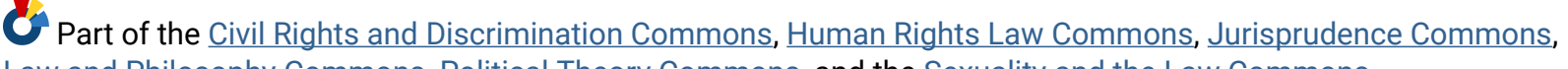
Law and Philosophy Commons, Political Theory Commons, and the Sexuality and the Law Commons 


\title{
Pluralism and Its Perils: Navigating the Tension Between Gay Rights and Religious Expression
}

\author{
Nan D. Hunter*
}

\author{
I. INTRODUCTION \\ II. The Georgetown “Gay Rights CaSe”: The Perfect Storm \\ III. EVOLUTION OF DOCTRINE SINCE GRC \\ IV. THE ROLE OF COURTS IN A KULTURKAMPF \\ V. CiVIL Rights MORALISM \\ VI. PluRAlisms \\ VII. CONCLUSION
}

\section{INTRODUCTION}

Gay Rights Coalition v. Georgetown University ${ }^{1}$ (GRC) exemplifies a rare breed of judicial opinion: one that has become a proverbial canary in a coal mine. It presaged what is emerging as the dominant question related to state regulation of sexuality for the next decade: the tension between lesbian, gay, bisexual, and transgender (LGBT) equality claims and claims to religious liberty.

In GRC, the D.C. Court of Appeals ruled both that a Roman Catholic university had to provide equal material benefits to gay student organizations, and that those organizations could be required to declare on stationery and in publications that the university did not endorse their activities. By doing so, the court granted victory to Georgetown University on expressive grounds and to the Gay Rights Coalition on equality grounds. In the end, both parties claimed victory. ${ }^{2}$

It is tempting to attribute this Solomonic and seemingly happy ending to the court's deft accommodation of the two worldviews represented in the case. The decision exemplifies reliance on pluralism as the central lodestar for

\footnotetext{
* Professor of Law, Georgetown University Law Center.

${ }^{1} 536$ A.2d 1 (D.C. 1987).

${ }^{2}$ A Gay Rights Victory at Georgetown, N.Y. TimES, Apr. 2, 1988, at A7, col. 1.
} 
navigating factionalism in the modern democratic state. The court built its resolution on an amicus brief from a Wisconsin civil rights agency that had suggested the specific compromise, ${ }^{3}$ adding an elaborate doctrinal path to reach its result. The decision has become something of a poster child for judicial minimalism: a model of wisdom, pragmatism, and statesmanship. ${ }^{4}$

The opinion in GRC was the first by a court of last resort to establish parameters for accommodating religious belief in the context of enforcing civil rights protections for gay plaintiffs. It will not, however, be the last. Today the volume of sexual orientation equality claims has dramatically increased. When the complaint in the Georgetown case was filed in 1979, the District of Columbia was the only state-level jurisdiction that prohibited anti-gay discrimination. ${ }^{5}$ When the case was decided nine years later, only Wisconsin had joined D.C. in banning sexual orientation discrimination. ${ }^{6}$ Today, antidiscrimination laws in twenty one states plus the District of Columbia contain this prohibition. ${ }^{7}$

Since GRC was decided, additional cases have arisen testing the accommodation of religious beliefs in the context of gay rights claims. ${ }^{8}$ In a case

${ }^{3}$ Brief for the Governor's Council on Lesbian and Gay Issues as Amicus Curiae Supporting Appellants, Gay Rights Coalition v. Georgetown University, 536 A.2d 1, 20 (D.C. Cir. 1987)(No. 5863-80).

${ }^{4}$ William Eskridge has been the leading scholarly voice in describing the GRC decision as exemplary for its pluralism-friendly mode of adjudication. See, e.g., William N. Eskridge and Gary Peller, The New Public Law Movement: Moderation as a Postmodern Cultural Form, 89 МicH. L. REV. 707, 750 (1991); William N. Eskridge, A Jurisprudence of "Coming Out": Religion, Homosexuality, and Collisions of Liberty and Equality in American Public Law, 106 YALE L.J. 2411, 2433-34, 2437, 2449-51 (1997).

${ }^{5}$ Gay Rights Coal., 536 A.2d at 33.

6 See State of Wisconsin Legislative Reference Bureau, Fair Employment, ANTIDISCRIMINATION, AND WORKER PROTECTION LAWS IN WISCONSIN, available at http://legis.wisconsin.gov/lrb/pubs/ib/08IB1.pdf (Wisconsin banned anti-gay discrimination in 1982); see also Anti-Discrimination Law in Massachusetts, GAY AND LESBIAN ADVOCATES AND DEFENDERS, http://www.glad.org/rights/massachusetts/c/anti-discrimination-law-in-massachusetts (Massachusetts was the next state to act; it banned anti-gay discrimination in 1989).

7 Non-Discrimination Laws, MOVEMENT AdVANCEMENT PROJeCT, http://www.lgbtmap.org/equality-maps/non_discrimination_laws (last visited Jan. 31, 2014).

${ }^{8}$ See, e.g., Elane Photography, LLC v. Willock, 309 P.3d 53 (N.M. 2013), cert. denied, 134 S. Ct. 1787 (2014); Catholic Charities of Me., Inc. v. City of Portland, 304 F. Supp. 2d 77 (D. Me. 2004); EEOC v. Preferred Mgmt. Corp., 216 F. Supp. 2d 763 (S.D. Ind. 2002); Doe v. California Lutheran High School Ass'n, 170 Cal. App. 4th 828 (Cal. Ct. App. 2009); Egan v. Hamline United 
in which the Supreme Court denied certiorari, a New Mexico retail photographic services business was found in violation of that state's antidiscrimination law after its refusal to photograph a same-sex commitment ceremony. ${ }^{9}$ In a different context, the Court has found that a for-profit business can assert a religious liberty claim. ${ }^{10}$ Several disputes related to employees of religious schools and service providers for weddings are in various stages of litigation. ${ }^{11}$

In the legislative arena as well, religious liberty concerns have increasingly surfaced as the primary area of dispute in the enactment of LGBT equality legislation. In the Senate's passage of legislation prohibiting sexual orientation and gender identity discrimination in 2013, the only floor amendment

Methodist Church, 679 N.W.2d 350 (Minn. Ct. App. 2004); Bernstein v. Ocean Grove Camp Meeting Ass'n, O.A.L. Dkt. No. CRT 6145-09 (Jan. 12, 2012) (holding that a Methodist organization that rented its facilities to the public could not distinguish between same-sex and different-sex ceremonies). In 2011, a state trial court judge upheld the decision by an Illinois agency to terminate its contract for foster care services with Catholic Charities because of discrimination against same-sex couples seeking to adopt. Manya Brachear, Catholic Charities Loses Ruling on Foster Care, CHICAGo TRIBUNE, Aug. 19, 2011. The group declined to appeal and ended its role in foster care. Manya Brachear, Catholic Dioceses Dropping Lawsuit over Foster Care, ChicAgo TriBune, Nov. 14, 2011. The Catholic Charities foster care and adoption agency in Boston also withdrew from providing the service rather than agree to accept same-sex couples as parents. Patricia Wen, Catholic Charities Stuns State, Ends Adoptions: Gay Issue Stirred Move by Agency, Boston Globe, Mar. 11, 2006. Cf. Levin v. Yeshiva University, 96 N.Y.2d 484 (2002) (finding that a religiously-affiliated university's policy of limiting certain housing to married students violated a municipal antidiscrimination law because of its disparate impact on same-sex couples). However, Yeshiva did not assert a Free Exercise or other religiously grounded defense. See generally, Robin Fretwell Wilson, The Calculus of Accommodation: Contraception, Abortion, Same-Sex Marriage, and Other Clashes Between Religion and the State, 53 B.C. L. REV. 1417, 1438-39 (2012).

${ }^{9}$ Elane Photography, 309 P.3d at 53.

${ }^{10}$ Burwell v. Hobby Lobby Stores, Inc., 134 S. Ct. 2751 (2014).

${ }^{11}$ See Edith Honan, Gay-Marriage Debate Takes New Twist in Oregon: Religious Exemption, REUTERS, Feb. 2, 2014 (describing current disputes in several states involving bakeries and florists that refused to provide services for same-sex weddings); Michael Paulson, Gay Marriages Confront Catholic School Rules, N.Y. TIMES, Jan. 22, 2014, at A1 (describing "a wave of firings and forced resignations of gay men and lesbians from Roman Catholic institutions across the country”). 
adopted concerned exemptions for religiously-affiliated employers. ${ }^{12}$ In state legislatures, bills extending marriage rights to same-sex couples have often triggered debate over the breadth of protection from liability for entities with various degrees of religious affiliation. ${ }^{13}$

One reason for the increased focus on exemptions from antidiscrimination mandates is that the facial constitutionality of such exemptions is uncertain. They can fall into a gray zone between the Free Exercise Clause and the Establishment Clause, neither necessary nor impermissible. ${ }^{14}$ Their absence does not significantly burden the beliefs or practices of those who adhere to various faiths, and they are not required by the Free Exercise Clause. Neither are they necessarily prohibited by the Establishment Clause, because they generally do not favor one religion over another, although they may favor religion over nonreligion. The precise location of where an exemption crosses the line in either direction remains unclear.

The cultural intensity associated with disputes like those surrounding homosexuality and religion illustrates the virtues of judicial restraint and of adjudication on the narrowest possible grounds. While minimalism in the service of pluralist accommodation can be a powerful virtue, these mechanisms for defusing conflict come at a cost. As Jed Purdy as written, pluralism in practice can seem "like riding a glass-bottomed boat over the colorful shoals of human values," ${ }^{15}$ but courts do not have the luxury of pleasure cruising merely to see the sights. Nor does it make sense to embark on every voyage with only the vaguest map from those who have gone before.

\footnotetext{
12 Jeremy W. Peters, Senate Approves Ban on Antigay Bias in Workplace, N.Y. TimEs, Nov. 7, 2013, available at http://www.nytimes.com/2013/11/08/us/politics/senate-moves-to-final-vote-onworkplace-gay-bias-ban.html.

${ }^{13}$ Wilson, supra note 8, at 1429 . Voters in Oregon may be the first to consider separate ballot initiatives: one to legalize same-sex marriage and another to create an exemption for businesses to decline services on religious grounds. Honan, supra note 11.

${ }^{14}$ Corporation of the Presiding Bishops of the Church of Jesus of Latter-Day Saints v. Amos, 483 U.S. 327, 334-35 (1987).

15 Jedidiah Purdy, Some Pluralism About Pluralism: A Comment on Hanoch Dagan's "Pluralism and Perfectionism in Private Law," 113 Columbia L. Rev. Sidebar 9, 10 (2013), http://columbialawreview.org/some-pluralism-about-pluralism-a-comment-on-hanoch-daganspluralism-and-perfectionism-in-private-law/.
} 
The GRC litigation was a particularly turbulent outing over those shoals, and it offers lessons for contemporary debates. The D.C. court's opinion also provides an apt beginning point for situating current LGBT equality versus religious liberty debates in a broader set of questions concerning the role of courts in navigating treacherous cultural terrain. This article re-examines the GRC decision with these two goals in mind and explores how it illuminates deficiencies in both doctrine and political theory.

The article is divided roughly in half between analysis of doctrine and of theory. I first critique the GRC decision doctrinally, focusing on the court's grappling with the expressive components of the two identities and the uncertainties surrounding the distinction between recognition and endorsement. $G R C$ was a particularly challenging dispute to resolve because of the then-new shifts in social meaning - that is, perceptions of the causes, consequences and normative valence of certain beliefs and conduct-that confronted the court at several levels of its analysis. I then update its analysis by examining how the Supreme Court in the years since GRC has dealt with the same doctrinal questions, identifying the inadequacies that remain. From there, I analyze a series of more theoretical problems that lay beneath the surface of a pluralist and minimalist approach to judging, including the proper role of courts, the problematic social meaning of antidiscrimination law, and the indeterminacy of both pluralist and religious belief systems.

More specifically, the order is as follows: In Part II, I tell the story of the GRC case and explain why it resonates so closely with current and likely future cases involving the conflict between gay equality and religious liberty. Simply put, three distinct dynamics converge in this category of cases:

- A conflict between two groups or representative parties driven by strong belief systems;

- A factual context in which questions of sexual morality are central; and

- A legal framework of antidiscrimination statutes.

These factors tend to trigger emotional responses that impede a proper weighing of the interests in contestation. Their cultural volatility also obscures the evolving social meanings that attach to each one of the three, thus greatly complicating the adjudicatory function. Disaggregating these points of tension is the first step in understanding the complex doctrinal mechanics in cases like GRC. 
I criticize the GRC court for its too-easy acceptance of the University's argument that its capacity to communicate adherence to Roman Catholic tenets on homosexuality would be irreparably spoiled by the presence of a gay student group. The court based its finding that the University violated the D.C. antidiscrimination law on evidence that the school's spoliation argument was tainted by stereotyping the student group as necessarily asserting support for every position in an imagined "gay agenda," including hostility to religion. ${ }^{16}$ This finding effectively limited the holding to the particular facts of the case. Where the court fell short, I argue, was in its failure to impose a duty on the larger, more powerful expressive actor to mitigate any harm to its message by assuming the burden to dissociate itself from the student group by engaging in more speech.

Part III explores cases in which the Supreme Court has confronted the central questions present in GRC since that case was decided. I focus on two themes. The first is whether an expressive institution's tolerance of the presence of an actor with a contrary message that contradicts the institutional speaker's message constitutes endorsement by the institution of that actor. Second, I trace how the Court has grappled with the inseparability of a status characteristic and a related expressive message.

I conclude that the law on both points remains unclear, but that it is also in motion. The Court has both deferred too easily to an expressive institution's spoliation argument (repeating the mistake in $G R C$ ), ${ }^{17}$ and, more recently, insisted on a duty to mitigate expressive harm by dissociation. ${ }^{18}$ When presented with an argument that lesbian, gay, or bisexual status, implicated by an antidiscrimination rule covering sexual orientation, could be separated from beliefs about the morality of homosexual conduct, the Court rejected the proposition that the two could be readily distinguished. ${ }^{19}$ Yet the Justices have not analyzed, or even fully engaged with, the complexities of expressive identity-based conflicts.

Part IV builds on the doctrinal analysis in Parts II and III and begins the shift to a more theoretical orientation. In Part IV, I argue for a substantial modification of the weight given to minimalist adjudication techniques-the "passive virtues" - that have garnered widespread support by scholars

\footnotetext{
${ }^{16}$ Gay Rights Coal. v. Georgetown University, 536 A.2d 1, 35 (D.C. Cir. 1987).

${ }^{17}$ Boy Scouts of Am. v. Dale, 530 U.S. 640 (2000).

${ }^{18}$ Rumsfeld v. Forum for Academic and Institutional Rights, Inc., 547 U.S. 47 (2006).

${ }^{19}$ Christian Legal Soc’y v. Martinez, 130 S. Ct. 2971 (2010).
} 
commenting on the judicial role in the culture wars. I propose three interpretive guidelines for lawmakers and lower courts confronted with conflicting normative visions: a default principle that civil obedience is ideologically neutral; a lodestar of enhancing voice and discouraging exit; and a commitment to protecting the right to dissent from the antidiscrimination principle.

In Part V, I explore the social meaning of antidiscrimination laws, the third problematic conceptual theme in GRC and one that is almost as culturally dense and contested in its meanings as are the concepts of religion and sexuality. Courts have upheld civil rights laws as viewpoint-neutral regulations of conduct rather than expressions of belief, but this understanding runs counter to a massive amount of descriptive commentary, as well as the history and popular discourse of civil rights. The moralistic vision of antidiscrimination law has persisted, even as civil rights laws have expanded to encompass issues directly related to sexuality. This combination draws demands from religious groups for exemptions, including Georgetown in the GRC litigation, on the theory that enforcement of LGBT equality laws creates unconstitutional viewpoint-based discrimination against conservative religious beliefs. The need for civil rights advocates to mobilize a rhetoric other than moral legitimacy has gone unacknowledged, and I argue that this should become a component of antidiscrimination discourse for the future.

Finally, Part VI interrogates the underlying concept of pluralism. I identify how two inconsistent models using the same nomenclature of pluralism have emerged in Free Exercise scholarship. I critique the newer model, which I characterize as based on the concept of "state as player," under which a truncated state takes a back seat to expansive individualist rights to accommodation of religious beliefs and practices. I endorse the state-as-umpire model, both because it supplies the necessary resolution in a cosmopolitan democracy and because it is the only approach that can effectively protect against the third-party harm that results from exemptions.

Issues related to sexuality constitute a primary site for the negotiation of pluralist values and challenges to those values. The epistemic dynamic is mutually constitutive. Specifically, conflicts surrounding equality rights for openly gay persons will redefine the cultural authority and social role of religious institutions, as they simultaneously affect the meaning of equality.

\section{The Georgetown “Gay Rights Case”: The Perfect Storm}


In 1978, lesbian, gay and bisexual student groups on the main campus and at the Law Center of Georgetown University sought recognition as official student groups. When the University refused, the student groups filed suit under the D.C. Human Rights Law, which had been amended three years earlier to prohibit discrimination on the basis of sexual orientation by public accommodations, including educational institutions. ${ }^{20}$ The University took the position that it could not accede to the D.C. law without acquiescing to coerced speech. It argued that granting official recognition to the gay student groups would communicate the University's endorsement of homosexuality, contrary to Catholic teaching. ${ }^{21}$

When GRC reached the D.C. Court of Appeals, there was no precedent in the context of LGBT equality for resolving the tension between the nation's dual commitments to equality of persons and tolerance for ideological dispute. In the plurality decision written by Judge Julia Cooper Mack, the D.C. Court of Appeals ruled that Georgetown University had to comply with D.C.'s prohibition by furnishing equal material, but not philosophical, support to gay student organizations. $^{22}$ The court thus split the atom of tolerance, separating what it described as the material from the expressive components of the antidiscrimination mandate.

The complexity of the issues produced a complex resolution, consisting of seven separate opinions in the final en banc decision, preceded by majority and dissenting opinions from a three-judge panel. ${ }^{23}$ Three components of the dispute converged to produce a particularly intense legal and social conflict. First, the dispute required adjudicating between two nomic identity communities, each of which had plausible legal claims. Second, the context of the dispute trenched on the particularly volatile cluster of social meanings surrounding homosexuality. ${ }^{24}$ Finally, the doctrinal framework in which the dispute arose was antidiscrimination law, a body of law that is itself not simply a mechanism for determining liability, but is also deeply inflected with suggestions of moral

${ }^{20}$ Gay Rights Coal., 536 A.2d at 10-14.

${ }^{21}$ Id. at $11-14$.

${ }^{22}$ Id. at 39.

${ }^{23} 496$ A.2d 567 (D.C. 1985), rev'd en banc, 536 A.2d 1 (D.C. 1987).

${ }^{24}$ See William N. Eskridge, Dynamic Statutory InTERPRETATION 198 (1994) ("What made Gay Rights Coalition a hard case was that one social construction ('homosexuals' as sick, immoral, or pathetic people) was giving way to another one (lesbians, gay men and bisexuals as a minority against whom discrimination is unjustifiable).”). 
legitimacy. In a reflection of the importance to it of the principles involved, the University sacrificed \$200 million in tax-exempt bonds that the District declined to offer while Georgetown was resisting enforcement of the antidiscrimination statute. ${ }^{25}$ Ultimately, the University President and Board of Directors acceded to the court's ruling despite pressure from counsel and Cardinal James Hickey to seek further review in the Supreme Court. ${ }^{26}$

Had any of these factors not been present, the emotional intensity register of this litigation would have been significantly lower. Even had the dispute been between the same two parties, for example, it would have not become an epic saga lasting a decade and achieving widespread notoriety if the context had been questions of scientific accuracy or if the legal framework had centered on contract or torts. Instead, a trifecta of cultural crisis points melded into a perfect storm. It is a storm that is likely to arise again.

The Georgetown case is conventionally - and not incorrectly understood as a battle of rights in which the liberty of religious expression and belief was pitted against equality claims. A better understanding, however, is that it was a battle of social meanings, or perhaps the first skirmish in one specific, continuing battle. Explicitly at issue in the framing of the parties' claims and defenses, and in the text of the opinion, were the meanings of the act of compliance with an antidiscrimination law, of openly expressed homosexuality, and of the distinction between endorsement and toleration. What is missing from Judge Mack's opinion is a deeper engagement with these social meanings and their legal and social consequences.

\section{A. The Role of Expressive Identity in the Georgetown Case}

In a dispute that pits claims of equality against those of religious liberty, the equality claims may arise from the Equal Protection Clause or from civil rights statutes. The religiously-affiliated defendant can disavow liability based on some or all of three branches of First Amendment law: free expression, the freedom of expressive association, and the free exercise of religion. The tests that

${ }^{25}$ Walter J. Walsh, The Fearful Symmetry of Gay Rights, Religious Freedom, and Racial Equality, 40 How. L. J. 513, 566-67 (1997).

${ }^{26}$ Id. at 564-66; Daniel Klaidman, 'Insulting and Intimidating': Williams \& Connolly's Tactics Are the Central Issue in the Battle Over Legal Fees in Georgetown Case, Legal TimEs, June 20, 1988, at 7, 10. 
a court must deploy to apply those defenses collapse into each other. ${ }^{27}$ In each, the court must determine whether enforcement of the equality claim would significantly burden the defendant's expression or religious beliefs or the capacity of an organizational defendant to associate for expressive purposes. If a burden is significant, the court must then assess whether there is a compelling state interest in enforcing the equality mandate and whether its interest could be achieved with comparable effectiveness by other means. The weight of the burden on the speaker determines how great the obligation is on the state to justify its action. State action that produces either silencing or coerced speech is generally per se invalid.

This analytic construct structures the dispute in unfortunate ways. It assigns equality interests to one party and expressive liberty interests to the other, when it is almost always true that both sides embody both values. The "equality plaintiff" is in fact communicating a message, and the "expressive defendant" is seeking recognition for the cluster of identity affiliations that produced the point of view it seeks to advance. Despite this complex social dynamic, constitutional doctrine has artificially disaggregated the speaker and the message - a nonsensical result in light of the way that social life is experienced.

In earlier work, I have described how what I have called the concept of expressive identity - the social reality of integration between the identity of the speaker and the viewpoint of her message-has cut across doctrines and confused constitutional law. ${ }^{28}$ Both protecting a group of people in a marginalized status category from discrimination and fostering space for anti-orthodoxy messages should be understood as part of the same project of furthering justice. Thus, if an expressive identity — such as "gay" or "Christian" —is to be protected, the scope of the equality protection for each group must include space for incorporating the intrinsic message behind the group identity, rather than allowing the message of either group (whether it is "gay is good" or "homosexual conduct is a sin") to negate the equality mandate.

The anomalies of legal doctrine that underlie the expressive identity conundrum have produced contradictory framings by gay plaintiffs. ${ }^{29}$ In First

${ }^{27}$ Cf. Christian Legal Soc’y v. Martinez, 130 S. Ct. 2971, 2985-86 (2010).

${ }^{28}$ Nan D. Hunter, Expressive Identity: Recuperating Dissent for Equality, 35 HARV. C.R.-C.L. L. REV. 1 (2000).

${ }^{29} I d$. at 30-31. 
Amendment cases against state actors, LGBT plaintiffs have pressed claims premised on dissent, with self-characterizations of LGBT identity as inherently expressive. In situations such as the Georgetown case, involving private sector defendants, LGBT plaintiffs have downplayed any expressive selfcharacterizations. In that type of case, the clearer the anti-orthodoxy viewpoint of the group of LGBT plaintiffs, the stronger the defense by a private institution that it cannot be dragooned into endorsement of ideas with which it disagrees.

The conundrum of expressive identity fractured the en banc court in GRC. Because GRC involved a private university, the students had no First Amendment claim and the University had no First Amendment obligation. What the Georgetown students did have was the District of Columbia antidiscrimination statute. Two judges asserted that the student groups represented a viewpoint regarding the moral legitimacy of homosexuality, and that the local civil rights law did not require Georgetown to treat all belief-driven groups equally. ${ }^{30}$ Judge Mack rejected this argument on the ground that the University had applied antiLGBT stereotypes in its rationale for non-recognition of the groups, thus placing its policy into the category of status-based discrimination. ${ }^{31}$ Without that evidence, however, the group's intrinsic “pro-gay” message could have defeated its claim under the antidiscrimination law. By extension, other openly LGBT persons and organizations could have been left unprotected against exclusions by private entities with an expressive function, as indeed later occurred with the Boy Scouts. ${ }^{32}$

Two other members of the court found that the expressive components of openly lesbian, gay, and bisexual identity had to be accepted as part of the equality claim, thus implicitly recognizing and endorsing the expressive identity critique. ${ }^{33}$ These judges considered it bogus for Georgetown to claim that its differential treatment of the lesbian, gay, and bisexual students could be separated from the very kind of bias that the antidiscrimination law was enacted to prohibit.

30536 A.2d at 65-66 (en banc) (Belson \& Nebeker, JJ).

31 Id. at 27-29. The court concluded that Georgetown "ascribed to the student groups only 'purposes and activities' which they may have had, but also a host of others automatically assumed to be a necessary attribute of their homosexual orientation." Id. at 28.

32 Boy Scouts of Am v. Dale, 530 U.S. 640 (2000).

${ }^{33}$ Id. at 56-60 (Ferren \& Terry, JJ). 
Based on the evidence of stereotyping, Judge Mack's opinion elided the conflict about whether the claim of the LGBT equality organization was better understood as challenging a private institution's hostility to gay students or as challenging the institution's protected right to express antipathy to the idea that homosexuality should be a neutral factor in its operating policies. This elision enabled the court to avoid taking a position on whether the foundation of the gay students group's claim was status or viewpoint. The court thereby ducked the question of the social meaning of toleration of contrary expression by a speaker with a sincere objection to a particular form of equality. The court achieved a compromise between competing normative visions only by avoiding the meaning of those visions.

The conceptual frame of expressive identity seeks to engage head-on with these anomalies. It incorporates these complexities by recognizing that the identity characteristic that grounds any equality claim is in fact an amalgam of status, expression, and often conduct. Religious affiliation and sexual orientation are perhaps the two clearest examples of such an amalgam: each characteristic melds a social demographic, a set of practices and, as Justice Kennedy described religion, "a specific premise, a perspective, a standpoint from which a variety of subjects may be discussed and considered." 34 The conceptual frame of expressive identity thus integrates the expressive aspects of any antidiscrimination claim as intrinsic to, rather than contradictory to, equality norms. In doing so, it offers a realistic appreciation that recognition claims are intrinsically communicative of ideas and beliefs.

The Supreme Court has noted the risk that pretextual claims of shared beliefs by an association could hide discriminatory policies of excluding certain persons. ${ }^{35}$ Assessing the sincerity of a group's expressive function can be tricky. In general, I would accord wide latitude for all expressive associations, including those of a religious nature, but I would not eliminate the judicial role of guarding against exemptions that are based on suspiciously recent central beliefs from antidiscrimination laws. As the number of such cases increases, the need increases for greater clarity of analysis as well, something the Court has not yet achieved.

\footnotetext{
${ }^{34}$ Rosenberger v. Rector, 515 U.S. 819, 831 (1995).

35530 U.S. at 653 (stating that "an expressive association can[not] erect a shield against antidiscrimination laws simply by asserting that mere acceptance of a member from a particular group would impair its message”).
} 


\section{B. Conflicting Views of "Endorsement"}

Baked into the problem of expressive identity is the contention that when an institution allows the presence of certain expressive actors, such as openly gay plaintiffs or groups, it is reasonable to infer that the institution has endorsed some variation of the belief that homosexuality is morally or socially acceptable. In the Georgetown case, the University rested its First Amendment defenses most heavily on the argument that recognition of the gay student organizations would be "interpreted by many" as an endorsement of homosexuality by the University. ${ }^{36}$ Georgetown thus alleged a burden on its expression rights because of what it asserted was the social meaning of recognizing the gay student groups.

The claim by Georgetown and similar institutions that their own expressive messages have been hijacked and twisted amounts to a spoliation defense - that is, that its religious position on homosexuality is spoiled by the presence of an openly gay student group on campus. My argument, in response, is two-fold. First, I agree that the first part of a proper doctrinal response is to employ an objective test of whether there has been spoliation of the speaker's message. I recognize, however, that objectivity is easier said than done; in a culturally-loaded context such as that in the GRC litigation, objectivity can seem like a chimera. Second, I argue that changing social meanings result in changing the degree of burden on expression (even under a properly objective test) and that this reality must be taken into account in the doctrinal analysis.

In her analysis for the D.C. Court of Appeals, Judge Mack eschewed objectivity. Instead, her opinion deferred to the University on gauging the expressive impact dynamics in the case. Not only did Judge Mack's opinion accept the University's understanding of the content of Roman Catholic tenets on the subject of homosexuality, as it should have, but it also deferred to the University's argument that recognition of a student organization would inevitably communicate endorsement of the activities and beliefs of that student organization. ${ }^{37}$ In the University's view, being required to recognize a gay student group, while otherwise taking no position on the group, was equivalent to

\footnotetext{
${ }^{36} 536$ A.2d at $11,13$.

${ }^{37}$ The panel had rejected this option. Gay Rights Coal. v. Georgetown Univ., 496 A.2d 567, 574 (D.C. 1985).
} 
mandated neutrality by the University regarding the group, which was in turn equivalent to endorsement of the group and hence, of homosexuality. Expert testimony by clergy advanced this argument as part of Roman Catholic doctrine. ${ }^{38}$ The University further argued that it would be seen as having endorsed not only the campus activities, but also whatever movement efforts and messages emanated from the entire gay rights movement beyond the campus. ${ }^{39}$

The court's acceptance of this analysis led to the conclusion that the D.C. statute could not require the University to recognize the gay student groups without violating the University's First Amendment right against coerced speech. ${ }^{40}$ In effect, the court defined a particular religious constituency as the relevant metric for determining the effect of compliance with a civil rights law, rather than the presumptively secular publics of the student body, the faculty, and neutral observers. The result was a fundamentally subjective analysis.

The court accepted this analysis without significant assessment of the reality of the University. Georgetown University is not a congregation or religious order, but a large university that has chosen to function in a national, secular academic environment. It does not limit the faculty, staff or student body by religious affiliation or adherence to tenets of the Roman Catholic faith. It is a full and flourishing member of the intellectual and economic marketplace of higher education. Central to the role of even private universities is their uniquely broad openness to all manner of viewpoints.

It is easy to criticize the finding of an endorsement effect from the perspective of twenty-five years later, all the more so in light of Georgetown's own changes. ${ }^{41}$ But, a defender of the decision for its pluralist value might argue, meanings shift; the social meanings of ideas are not frozen. Surely there is no better example of that than debates over equality rights for lesbians and gay men. Gay identity signifies an issue and a group that was once seen as "beyond the

\footnotetext{
38536 A.2d at 15.

${ }^{39}$ Id. at $13,29-30$.

${ }^{40} \mathrm{Id}$. at 21.

${ }^{41}$ See, e.g., Kyle Spencer, A Rainbow Over Catholic Colleges: How Georgetown Became a GayFriendly Campus, N.Y. TIMES, Jul. 30, 2013, http://www.nytimes.com/2013/08/04/education/edlife/how-georgetown-became-a-gay-friendlycampus.html?pagewanted=all\&_r=0.
} 
pale," 42 but gay equality now harmonizes with civil rights more generally, with increasing success in the political arena. Only two years before the en banc decision, the Supreme Court ruled that same-sex partners had no constitutionally protected right to sexual privacy. ${ }^{43}$ Perhaps the contention that gay presence implied endorsement, however strained now, was at least plausibly right then.

Even if we assume for purposes of argument that the court was correct to accept Georgetown's claim that the presence of a gay student group might create the perception that the University endorsed homosexuality or gay rights, the court should not have stopped its analysis there. First Amendment law requires an inquiry into whether the speaker whose message is allegedly being coerced nonetheless has the power to eliminate the distortion of its views by affirmative dis-attribution-i.e., by taking steps to communicate its non-endorsement of certain messages, in ways that will reasonably counter any false perceptions of agreement. $^{44}$

The duty to mitigate spoliation of one's message by dissociation from the spoiler provides courts with a mechanism for allocating the burdens of tolerance and dissent in a dispute over expressive space. As cultural shifts alter the perception of endorsement, the burden of disassociation will become lighter.

In GRC, the appellate panel and the en banc court parted ways at this step of the analysis. ${ }^{45}$ The panel had accepted, arguendo, Georgetown's fear of a perception of endorsement, but had concluded that there were many mechanisms available to the University for distancing itself from a gay student group and clarifying that it did not accept the group's message. ${ }^{46}$ Such actions, the panel reasoned, would mitigate any burden on the University's First Amendment rights.

The en banc court resolved the endorsement/dissociation question in precisely the opposite way. Unlike the panel, the en banc court accepted the trial court's factual finding that the spoliation of the University's message by the gay

42 Gay Students Org. of Univ. of N. H. v. Bonner, 509 F.2d 652, 658 (1st Cir. 1974) ("The underlying question, usually not articulated, is whether, whatever may be Supreme Court precedent in the First Amendment area, group activity promoting values so far beyond the pale of the wider community's values is also beyond the boundaries of the First Amendment.").

43 Bowers v. Hardwick, 478 U.S. 186, 186 (1986).

${ }^{44}$ See infra text accompanying notes 64-67.

${ }^{45}$ Compare 536 A.2d at 19 (en banc) with 496 A.2d at 574 (panel).

${ }^{46} 496$ A.2d at 580. 
student group was irreparable. ${ }^{47}$ For that reason, Judge Mack's opinion for the en banc court concluded that Georgetown did not need to recognize the student group, although it was required to provide the group with various material supports. Judge Mack's opinion left undecided any issue of disassociation. ${ }^{48}$ During settlement agreements following the court's decision, ${ }^{49}$ the burden of dissociation eventually came to rest on the student groups, requiring the groups to state affirmatively that, despite their use of the name "Georgetown," there was no official university recognition of the groups. ${ }^{50}$

The GRC court's treatment of both prongs of the relevant doctrine was inadequate: it gave short shrift to the need for an objective standard for assessing whether there is perceived endorsement when a university recognizes a student group, and it failed to address a duty of mitigation on the part of the university. In the end, the D.C. court developed its own approach to the allocation of discursive space, but without articulating a coherent rationale to assist courts in later cases.

\section{The Role of Antidiscrimination Law in GRC}

What no doubt astounded Georgetown University and its lawyers in the 1980's was that their position condemning homosexual conduct, grounded in clear religious doctrine, was seen as only morally equivalent - rather than morally superior - to the implicit normative premise of a statute that forbade differential treatment based on sexual orientation. In its ultimate resolution of the conflict, the D.C. Court of Appeals in effect granted that the University had a moral autonomy right to take a normatively wrong position, but held that the antidiscrimination law constrained the University from imposing material harm as a result of its position. ${ }^{51}$

\footnotetext{
${ }^{47} 536$ A.2d at 19. The en banc court declined to review this finding de novo, instead ruling that it was not clearly erroneous. Id. The University's contention was heavily muddied by its simultaneous acceptance of other student groups with messages contradicting Roman Catholic orthodoxy. 496 A.2d at 573-74. In addition, the university never sought to ban gay student groups from campus entirely. Id. at 574 .

48536 A.2d at 14 n.12; id. at 46 (Newman, J., concurring).

${ }^{49}$ A Gay Rights Victory at Georgetown, supra note 2.

${ }^{50}$ Consent Agreement (on file with author).

${ }^{51} 536$ A.2d 1 (D.C. 1987).
} 
The association of this cluster of moral meanings with antidiscrimination law forms no part of any judicial holding of which I am aware, although the Supreme Court's decision in Bob Jones University v. United States ${ }^{52}$ comes close. The Court in Bob Jones held that the public policy against racial segregation was so strong that it trumped the right of a conservative Christian college to maintain a discriminatory admissions policy based on its religious beliefs. ${ }^{53}$ Although multiple utilitarian arguments about the value of diversity to the quality of education can justify antidiscrimination requirements, it seems a stretch to imagine that the court would have disallowed a religion-based exception had the only state interest been that of encouraging high standards in university education. Instead, the power of the Bob Jones decision lies in its normative punch.

In $G R C$, the court addressed the related question of whether the District had a compelling interest in eradicating sexual orientation discrimination. In the first appellate opinion, the panel held that this goal was equally “"compelling' or 'overriding'” as the interest in eliminating discrimination based on race or sex, and cited Bob Jones as controlling precedent for the proposition that antidiscrimination goals outweighed religious liberty interests. ${ }^{54}$

Judge Mack, the third member of the original panel, dissented from its judgment in part because she disagreed with this reading of Bob Jones. To her, "the majority's equation" of race and sexual orientation discrimination, in light of the constitutional history associated with the former, was "far-fetched." 55 In her opinion for the full court, Judge Mack walked back the implications of her "farfetched" characterization in a lengthy section of the en banc opinion that recounts the history of discrimination based on sexual orientation. Although it describes such discrimination as an "evil," 56 the court acknowledged approaching this part of its analysis with "more than a little trepidation." 57 Except for a few passing references, ${ }^{58}$ the Bob Jones decision is not mentioned.

52461 U.S. 574 (1983).

${ }^{53} \mathrm{Id}$. at 604 .

54496 A.2d at 576.

$55 \mathrm{Id}$. at 586.

56536 A.2d at 32.

${ }^{57} \mathrm{Id}$. at 33 .

${ }^{58}$ Id. at $32-33$. 
In the dispute over comparing discrimination based on sexual orientation to that based on race, both sides realized that an important cultural good was at stake. The most valuable resource that Georgetown lost in the GRC litigation was not the avoidance of extending relatively insignificant material benefits to the gay student groups. Rather, its major loss was the exclusivity of its claim to moral superiority in the public sphere, a position that in turn had served to reaffirm the superiority of its private definition of morality.

\section{Summary}

We have seen in this part how deeply contingent the decision in the Georgetown case was on social meanings in three key dimensions: the expressive connotations of both gay identity and religious affiliation; the contested interpretations of which actions communicate "endorsement" of a position or viewpoint; and the normative implications of a judicial finding that the university violated a civil rights law.

My critique thus far has been primarily doctrinal. Judge Mack and those who have celebrated the decision, however, would doubtless argue that doctrinal deconstruction misses the bigger points: that the court's compromise solution enabled both parties to retain their dignity and fostered future dialogic engagement. In the historical context of the 1980s, this assessment may be correct. But we must also ask how best to protect and foster cultural diversity now.

Beginning in Part IV, infra, I will address broader questions of political theory raised in GRC and similar cases. Before reaching those points, however, it is important to bring the doctrinal analysis up to date.

\section{EVOLUTION OF DOCTRINE SiNCE GRC}

Since GRC was decided, the Supreme Court has been forced to confront the same three tensions present in the Georgetown case. The result has been a mixture of partial clarification and uneven reasoning, with patches of emotionalism.

\section{A. Spoliation and Endorsement}


In Boy Scouts of America v. Dale, the Court found that the Scouts' right to expressive association barred New Jersey from applying a law against sexual orientation discrimination in the selection of an assistant scoutmaster. ${ }^{59}$ Although Dale can be read as superseding GRC, it can also be distinguished: Dale involved a leadership position in an organization for children and adolescents, rather than the presence of one among many student groups available to young adults in a university setting. What is consistent in both GRC, and Dale, however, is the courts' avoidance of the feasibility of dis-attribution.

The expressive association test that the Court used in Dale asked only what would be the burden of Dale's presence on the Scouts' ability to disseminate their chosen message. The Court deferred, in a perfunctory manner, to the Scouts' assertion that it taught that homosexual conduct is morally wrong and that the presence of a gay assistant scoutmaster would significantly burden its expressive integrity. ${ }^{60}$ The primary dissent argued that the Scouts had failed to demonstrate a meaningful burden, both because of lack of evidence that its views on homosexuality were consistent and unequivocal over time and because of the excess significance being accorded to homosexuality. ${ }^{61}$ But neither opinion engaged directly the importance of assessing whether the excluder could effectively disassociate itself from the party seeking inclusion. The absence of that step in the doctrinal analysis enabled the majority's too-easy finding of an unconstitutional burden.

Thus, the dissociation point escaped analysis. All of the Justices alluded to changing popular opinion on homosexuality, ${ }^{62}$ but none understood why changing popular opinion was relevant. Justice Stevens's references to specific indicia of this change seemed to be intended as a counter to, and a calling-out of, more conservative views as "atavistic." 63 The imprecision of his references elicited distancing comments from his fellow dissenters. Shifts in popular opinion did not, as Justice Souter's separate dissent correctly stated, affect in any way whether the

\footnotetext{
59530 U.S. 640 (2000).

${ }^{60} \mathrm{Id}$. at $651-52$.

${ }^{61} I d$. at 668-78, 696 (Stevens, J., dissenting).

${ }^{62}$ Id. at 660, 699-700 (Stevens, J., dissenting), 701 (Souter, J., dissenting).

${ }^{63}$ Id. at 699 (Stevens, J., dissenting).
} 
Scouts' views were entitled to presumptive protection under the First Amendment. ${ }^{64}$

What is important about changes in public opinion regarding LGBT equality is that they reflect shifts in social meaning that undercut the weight of the expressive burden on the Scouts. This dynamic should have been factored into the Court's analysis. The Scouts asserted that including an openly gay Scoutmaster would create the perception that the Scouts endorsed homosexuality, the same argument made by Georgetown. ${ }^{65}$ This argument depends on both the assumption that a reasonable observer would draw that conclusion and that there were no effective dissociation steps that the Scouts could take to counter it.

As homosexuality becomes more accepted in the society at large, the reasonable person's interpretation of gay presence changes. The evolving opinions either in favor of or neutral about homosexuality do not disqualify antigay opinion from First Amendment shelter. But they do affect the calculus as to what is a reasonable duty to mitigate by dissociation because they increase the likelihood that such dissociation will be effective. To the extent that efforts to dissociate succeed, the spoliation of the anti-gay speaker's message diminishes.

For these reasons, determining who bears the burden of dissociation or dis-attribution in this situation is critical. For expressive harm as for material harm, the law should place the burden on the party with the greatest capacity to absorb it, generally the party having the greatest capacity to disseminate its own views. If there is risk that reasonable persons would perceive that $X$ 's tolerance of Y's presence signals a change in X's worldview, then fashioning a remedy that requires $\mathrm{X}$ to generate more expression increases the articulation of both antiLGBT and pro-LGBT views and strengthens the norm of tolerance.

One could object that to understand legal outcomes as turning on cultural changes is to invite ambiguity and judicial over-reaching. It is precisely the dissociation test that could alleviate that risk, however. Asking whether concrete mechanisms exist by which the excluder could effectively communicate its own views, despite an unwanted expressive identity presence, would constitute a test for allocating the burdens of tolerance and dissent that is far more consistent with norms of both equality and expression than the deference employed by the courts in GRC and Dale.

\footnotetext{
64530 U.S. at 701 (Souter, J., dissenting).

${ }^{65}$ Id. at 651 (majority opinion).
} 
In two other cases, analogous in different ways to GRC, the Court did employ a dissociation test. Both involved a university that asserted spoliation of expression: that either funding for a student religious group or the presence of military recruiters would undercut the message intended by the university. In Rosenberger v. Univ. of Virginia, a public university argued that paying expenses for a Christian student publication would so distort the university's policy of neutrality that it would create an Establishment Clause violation. ${ }^{66}$ In Rumsfeld $v$. Forum for Academic and Institutional Rights, Inc. (FAIR), a consortium of law schools challenged a statute requiring that military recruiters have equal access to campus placement services. ${ }^{67}$ The schools argued that compliance would undercut their policies against allowing entities with discriminatory employment policies to recruit on campus. ${ }^{68}$ In both Rosenberger and FAIR, the Court found that the burden on speech could be sufficiently mitigated by university efforts publicizing their own messages of neutrality or commitment to equality, respectively. ${ }^{69}$

One may argue that Dale and FAIR can be distinguished from each other and from GRC by the particular branch of First Amendment law that was found to be decisive. Both the Scouts and FAIR asserted a combination of expressive association and coerced speech claims. The Court decided Dale on expressive association grounds, and FAIR on coerced speech grounds. For some purposes, the two doctrines appropriately diverge. In expressive association law, and not in coerced speech litigation, the court must inquire as to the bona fides of the expressive characteristics of an organization and whether the views in contention have in fact been consistently, repeatedly expressed. ${ }^{70}$ For the individual or organization claiming that expression is being commandeered in service of a particular message, the history of past views is largely irrelevant.

But both are branches of law in service of the same principles. When there is a conflict in rights, as there is in claims to inclusion in a venue that is itself communicative, the same balancing of expressive burdens should attach. The question of whether the impact on the message of the excluder can be mitigated by reasonable steps to dissociate from the intruder should factor into both

\footnotetext{
66515 U.S. 819 (1995).

67 547 U.S. 47 (2006).

68547 U.S. at 68.

${ }^{69} 515$ U.S. at 839-41; FAIR, 547 U.S at 64-65.

${ }^{70}$ Cf., Boy Scouts of Am., 530 U.S. at 648.
} 
analyses. The outcomes in both categories of cases should foster the purposes and normative values of freedom of both expression and equality.

\section{B. Untangling Expressive Identity}

The most recent case in which the Supreme Court has directly grappled with the expressive identity conundrum is Christian Legal Society v. Martinez. ${ }^{71}$ Here, the Christian Legal Society (CLS) cast itself as the functional equivalent of the Boy Scouts in Boy Scouts Association v. Dale: ${ }^{72}$ a norm-driven expressive association that excluded persons based on the particular combination of beliefs, status and conduct that antidiscrimination laws have treated as sexual orientation. In its reasoning, the Court acknowledged the expressive aspects of conflicting identities more directly than it ever had before

In CLS, the Court considered antidiscrimination claims by a conservative religious student group that challenged the policy of a public university limiting recognition to organizations that allowed all students to participate in all recognized organizations. CLS argued that denying it recognition constituted a viewpoint-based exclusion from a limited public forum, in violation of its expressive association rights. CLS contended that its policy of excluding thoseincluding lesbian, gay, and bisexual students-who did not comport with its philosophy that only heterosexual intimacy within marriage could be moral amounted to limiting membership eligibility based on viewpoint. In any event, CLS argued, it did not discriminate based on the per se status of sexual orientation. $^{73}$

Faced with this Boy Scouts-like argument, the Court distinguished the case from Dale because the right of CLS to continue its membership policies without recognition as a student group was not in question. CLS had other options. ${ }^{74}$ The majority declined to attempt to disaggregate the components of expressive identity. Nonetheless, the five majority Justices acknowledged that these

71130 S.Ct. 2971 (2010).

72530 U.S. 640 (2000).

73130 S. Ct. at 2990.

${ }^{74}$ Id. at 2975. At issue in Dale was whether the Scouts could continue to operate in New Jersey. Cf., Dale, 530 U.S. at 648. 
characteristics congealed into one meaningful concept of identity. In that, they were joined, albeit backhandedly, by the dissent.

\section{The Boy Scouts Redux Strategy}

CLS is an association of law students and lawyers with chapters at a number of law schools. When the Hastings College of Law chapter of CLS sought official university recognition, it was denied on the ground that CLS violated the Hastings requirement that recognition would not be granted to student organizations that discriminated based on certain specified grounds, including sexual orientation. During the litigation, Hastings specified that the nondiscrimination requirement also meant that student organizations had to accept all students as participants, members, or leaders "regardless of their status or beliefs." 75 Hastings took no position on the morality of any form of sexual conduct.

CLS refused membership to anyone who disagreed with its belief that "sexual activity should not occur outside of marriage between a man and a woman ... . [including] anyone who engages in unrepentant homosexual conduct." ${ }^{, 76}$ When its request for official student organization status was denied on the ground that it violated the antidiscrimination policy, CLS contended that the state through its public university was prohibited from penalizing CLS's right of expression and association based on a requirement of equal treatment that conflicted with the organization's views on sexual morality.

"[T]his is an a fortiori case under Dale," CLS argued, ${ }^{77}$ citing the Scouts' right to exclude Dale because his inclusion would subvert the Scouts' right to express its view that homosexuality was incompatible with Scouting. Like the Scouts, CLS emphasized, it too based its exclusionary policy on its beliefs. Therefore, it could not be required to admit all comers, including those who manifestly disagreed with its philosophy, a group that included, but was not limited to, lesbian, gay, and bisexual students. CLS asserted that it could not

\footnotetext{
75130 S. Ct. at 3005.

${ }^{76}$ Id. at 2974.

77 Brief for Petitioner at 45, Christian Legal Society v. Martinez, 130 S. Ct. 2971 (2010) (No. 081371), 2010 WL 711183, at *45.
} 
effectively continue to communicate its viewpoint if it was forced to accept members who disagreed.

The Court rejected the argument. Agreeing that the "First Amendment shields CLS against state prohibition of the organization's expressive activity," the Court nonetheless ruled that, while the holding in Dale fell within the scope of that principle, the facts in CLS did not. ${ }^{78}$ At issue was not a prohibition of expression but the denial of a form of public subsidy. Using the all-comers policy as the basis for subsidy decisions was justified, the Court found, as a reasonable way to administer the system of student organizations.

\section{Hinting at Expressive Identity}

The CLS litigation was complicated by a dispute over whether Hastings had in fact relied on an all-comers requirement to deny recognition or whether the denial was based on solely the antidiscrimination mandate. If the latter, CLS contended that other student groups were allowed to exclude based on viewpoint, and that it, as a religious organization, was singled out as ineligible to control its membership in that way. Chief Justice Roberts was sympathetic to the ramifications:

[G]ender or race is fundamentally different from religious [belief]. Gender and race is a status. [sic] Religious belief, it has to be based on the fundamental notion that we are not open to everybody. We have beliefs, you have to subscribe to them. And we have always regarded that as a good thing. ${ }^{79}$

In the trial court, the parties had stipulated that to secure formal status, a student group had to allow "any student" to participate, using as an example that a Democratic club had to admit Republicans. ${ }^{80}$ Hastings denied the allegation that the all-comers policy was not being enforced or that CLS was turned down on other grounds. ${ }^{81}$ In the Supreme Court, however, CLS argued that the earlier

\footnotetext{
78130 S. Ct. at 2978.

79 Transcript of Oral Argument at 46-47, 130 S. Ct. 2971.

${ }^{80} 130$ S. Ct. at 2982.

${ }^{81}$ Cf., 130 S. Ct. at 2995 (2010).
} 
version of the policy had been applied, that prohibited discrimination but did apply the all-comers policy in all instances and that, in any event, both versions of the policy were unconstitutional.

Based on the stipulation, Justice Ginsburg's opinion for the Court analyzed only the all-comers policy, accepting that it was applied equally to all student groups. In response to the CLS argument that even with an accept-allcomers policy, Hastings had a constitutional obligation to allow viewpoint-based exclusions for a viewpoint-based group, the Court demurred from imposing such a difficult enforcement task on the university. The CLS demand that "Hastings permit exclusion because of belief but forbid discrimination due to status . . . would impose on Hastings a daunting labor. How should the Law School go about determining whether a student organization cloaked prohibited status exclusion in belief-based garb?”82

The majority opinion implied that viewpoint was inseparable from identity or status, at least for a religious group. The Court acknowledged the assertion by CLS that it did not "exclude individuals because of sexual orientation, but rather 'on the basis of a conjunction of conduct and the belief that the conduct is not wrong." 83 In the next sentence rebutting the point, the Court substituted "status" for "the belief that the conduct is not wrong": "Our decisions have declined to distinguish between status and conduct in this context." ${ }^{84}$ Fairly read, the two sentences strongly suggest recognition that the concept of "status" encompasses a message that one believes that the conduct defining the status is moral. This precise combination constitutes expressive identity.

Justice Stevens, in concurrence, went further and argued explicitly that the identity status associated with religious affiliation or homosexuality necessarily and correctly incorporates viewpoint. ${ }^{85} \mathrm{He}$ more clearly recognized the category of expressive identity but without labeling it as such. He agreed with the main opinion as to the validity of the all-comers policy, but also found that Hastings could have enforced a ban on sexual orientation discrimination against a religious student group, even if other clubs were allowed to limit membership based on a shared philosophy. To do otherwise, he said, would eviscerate the goal of barring

82130 S. Ct. at 2990 (emphasis in original).

${ }^{83} \mathrm{Id}$.

${ }^{84} \mathrm{Id}$.

${ }^{85}$ Id. at 2996 (Stevens, J., concurring). 
status-based discrimination: “A person's religion often simultaneously constitutes or informs a status, an identity, a set of beliefs and practices, and much else besides. (So does sexual orientation for that matter . . .).”86

The four dissenting Justices would have found both versions of the policy unconstitutional. The original policy, Justice Alito wrote, constituted viewpointbased discrimination because its effect was to bar only religious groups from excluding members who did not share their beliefs, and because it discriminated against groups, like CLS, that expressed a viewpoint on sexual morality not shared by the University. ${ }^{87}$ Implicitly, this opinion also grasped the basic truth behind the concept of expressive identity: that social identity is too capacious to be distilled into two pure categories, one status, one viewpoint. Although the members of the court diverged over how to apply the insight, they appear to have all agreed that sexual orientation and religion both exemplify this concept.

Justice Alito concluded that, even if the viewpoint was neutral on its face, the all-comers policy was adopted as a pretext for discriminating against the religious group. ${ }^{88}$ His dissent raised the question to which we will return in Part IV: whether antidiscrimination policies, when enforced against religious entities on behalf of gay plaintiffs, are themselves the reflection of bias. Four members of the Court appeared ready to adopt the CLS argument that enforcement of the antidiscrimination policy created a disparate negative impact on religious entities that express a belief that homosexual conduct is morally wrong. ${ }^{89}$

\section{Summary}

The law's treatment of expressive identity remains unclear. The Supreme Court has both declined to factor in the duty to dissociate when the presence of an equality claimant would arguably spoil the message of an expressive institution (Dale), and has also insisted on such a duty (FAIR). The Court has recognized the complexities of the combined and mutually reinforcing effects of conduct, status, and viewpoint. As with the ambivalent guidance regarding a duty to dissociate, however, it has not clarified a mode of analysis for expressive identity claims.

${ }^{86}$ Id. at 2996 n.1.

${ }^{87} \mathrm{Id}$. at 3011-12 (Alito, J., dissenting).

${ }^{88} \mathrm{Id}$. at 3015-17.

${ }^{89}$ CLS Brief at 37-39. 


\section{The Role OF COURTS IN A KULTURKAMPF}

In the wake of backlash that is often mobilized around the theme of "judicial activism," American courts and scholars have sought shelter in a renewed emphasis on the virtues of judicial modesty and restraint. Especially but not only in cases that arouse strong public reactions, there is broad agreement that courts should rely on a minimalist or passive approach to adjudication. ${ }^{90}$ LGBT equality cases provide a particularly stark challenge to judges, one that has literally threatened the judicial function by producing election campaigns against judges who have voted to legalize same-sex marriage. ${ }^{91}$

Judicial minimalism is the jurisprudence of pluralism, providing a buffer zone both for the interest groups involved and for the judges themselves.

It functions as a philosophical speed bump, a warning that courts should proceed with prudence and caution when a dispute enters the field of highly contested religious and moral values. More deeply, the underlying goal of minimalism is to enhance the processes of democratic deliberation by which such issues can be resolved by politically accountable decision makers, outside the often zero-sum world of litigation. ${ }^{92}$

Judge Mack's opinion in GRC is a model of such minimalism. It rejected the all-or-nothing litigation posture of the parties in GRC, and deployed several standard techniques for "leaving things undecided": emphasizing statutory rather than constitutional grounds, limiting the resolution to the distinctive facts of the particular set of circumstances, and eschewing the announcement of broad rules for future cases. Its result was to foster dialogic engagement between the parties: in fact, they negotiated a settlement agreement that embodied the principles of the decision. Since that time, conditions for LGBT students at Georgetown have greatly improved. ${ }^{93}$

\footnotetext{
90 Cass R. Sunstein, One CaSe at a Time: Judicial Minimalism on the Supreme Court xi (1999) ("The current Supreme Court embraces minimalism. Indeed, judicial minimalism has been the most striking feature of American law in the 1990's.”).

91 A.G. Sulzberger, Ouster of Iowa Judges Sends Signal to Bench, N.Y. TimEs, Nov. 3, 2010, available at http://www.nytimes.com/2010/11/04/us/politics/04judges.html?_r=0.

92 See Sunstein, supra note 92, at 5, 24-28.

93 See supra text accompanying notes 63-66.
} 
The value of judicial minimalism in a constitutional democracy is selfevident but not unmixed. Moreover, "maximalism" is not the only alternative. Rather than broad pronouncements of principles to govern future cases, courts could deploy much more focused burden-shifting mechanisms. In this Part, I identify three broader principles that would decrease the ambiguous nature of minimalism-driven results without sacrificing the advantages of judicial restraint. The duty to dissociate discussed above is one such specific doctrinal device. Consider the following to be a suggestion for judicial minimalism 2.0.

\section{A. Civil Obedience}

One problem circulating in the background of religious liberty defenses to equality claims is that changes in social meaning can and do produce changes in law, and thus can be decisive of legal disputes. Neutral principles are not unchanging principles. The facts in GRC illustrate it well: as we have seen, Georgetown asserted that its recognition of the gay students groups would have created the perception, at least in the minds of some, that the university endorsed homosexuality, thus spoiling its own message. I have suggested that this was not an unreasonable claim 30 years ago when the case was being litigated, although it would be today. I have also argued that the D. C. Court of Appeals was nonetheless mistaken in its analysis of endorsement because it did not explore the means available to the University to cure any spoliation by affirmative disattribution.

But there is a more fundamental criticism that relates to the expressive functions of law. Georgetown's argument depended on the premise that compliance with a law of general application sends any message at all. The relevant baseline question should be not whether voluntary university recognition would have created a perception of endorsement, but whether mandated compliance with a law would have created such a perception.

To analyze whether the extent of the burden on religion caused by obedience with a law is justified, courts examine the state's interest in enacting the law. The Supreme Court has found that some burdens are not justified ${ }^{94}$ and that other burdens are overridden by the public interest served by the law. ${ }^{95}$ The

\footnotetext{
94 See, e.g.,Wisconsin v. Yoder, 406 U.S. 205 (1972).

95 See, e.g., Employment Division of Oregon v. Smith, 494 U.S. 872 (1990).
} 
problem with this analysis is that it skips an important threshold step: consideration of whether the acts necessary to comply with the law are expressive or merely instrumental. Some are expressive; some are not. I agree that individual religious actors may experience obeying a particular law as a burden, and I would not find all such burdens acceptable. Not wearing a yarmulke when one's faith demands it as a sign of respect to God, ${ }^{96}$ or being forced to work on the day one believes to be the Sabbath, ${ }^{97}$ are intrinsically expressive acts that generally create no harm to third parties. They are qualitatively different from paying income tax or administering a business or an institution that is a public accommodation. Absent a literal forcing of expression ${ }^{98}$ or coercion of specific, highly personal actions contrary to the religious commands of a certain faith, civil obedience is not the same as agreement.

The premise that ministerial acts of civil obedience are not expressive is well-established. It has long been a part of the jurisprudence of antidiscrimination law in the context of race. Whites who resisted integration feared loss of business if they voluntarily desegregated because their customers might perceive them as agreeing with practices of racial mixing. The law that made desegregation compulsory protected them against that risk. ${ }^{99}$ The same understanding attached to arguments by a religious school that admission of African-American students would undercut its belief that segregation had a Scriptural basis:

Although the school leadership's voluntary enrollment of blacks might communicate such a message, desegregation in response to a federal court's implementation of the congressional mandate of $\S 1981$ would not. Much as merchants were freed by the Civil Rights Act of 1964 from any fear that white customers react adversely to the acceptance of black business, parents and school leaders are freed by $\S 1981$ from any fear that

\footnotetext{
96 Goldman v. Weinberger, 475 U.S. 503 (1986).

97 Sherbert v. Verner, 374 U.S. 398 (1963).

98 Wooley v. Maynard, 430 U.S. 705 (1977) (state could not constitutionally require individual to display the words "Live Free or Die" on his license plate).

99 Gavin Wright, Sharing the Prize: The ECONOMics of the Civil Rights Revolution IN THE SOUTH 77, 101-02 (2013).
} 
children will interpret acceptance of blacks as an indication of church approval of the practice. ${ }^{100}$

The school at issue in this case was typical of a much broader phenomenon. The number of private all-white Christian schools mushroomed in the 1960s and 1970s in the South, a development that most observers attributed primarily to the effort to avoid desegregation. ${ }^{101}$ The Southern Regional Council, for example, stated in 1973 that "Christian schools and segregation academies are almost synonymous." 102

In those cases, courts recognized that the excess social significance of race should not be permitted to down the presumptive neutrality of civil obedience. In the vast range of business and other institutional practices, acts that are required to obey a neutral law send no signal as to the wisdom of that law. The Supreme Court's decision in Hobby Lobby took a dangerous step back from that understanding.

In Hobby Lobby, the Court held that requiring closely-held corporations to comply with a mandate to provide health insurance coverage for certain contraceptives violated the Religious Freedom Restoration Act when the corporate owners objected to such coverage based on their religious beliefs. ${ }^{103}$ The Court characterized its holding as "very specific" to that factual context ${ }^{104}$ and "concerned solely with the contraceptive mandate." ${ }^{105}$ The case presented a threat of "severe" economic consequences to the plaintiffs of non-compliance, ${ }^{106}$ coupled with "precisely zero" negative impact on third parties, ${ }^{107}$ because of an already existing mechanism created by the government for providing exemptions

100 Brown v. Dade Christian Schs., 556 F.2d 310, 321-22 (5th Cir. 1977) (Goldberg, J., concurring).

101 JosePH CRESPINO, In SEARCH OF ANOTHER COUNTRY: MisSisSiPPI AND tHE CONSERVATIVE Counterrevolution 248-50 (2007); DAVID NeVIN and Robert E. Bills, The Schools That FEAR BUILT: SEgREgATIONIST ACADEMIES IN THE SOUTH (1976).

102 Id. at 248.

103 Burwell v. Hobby Lobby Stores, Inc., 134 S. Ct. 2751, 2759 (2014).

${ }^{104}$ Id. at 2760.

105 Id. at 2783.

${ }^{106}$ Id. at 2775.

${ }^{107}$ Id. at 2760 . 
to nonprofit entities. ${ }^{108}$ The Court specifically disavowed "the possibility that discrimination in hiring, for example on the basis of race, might be cloaked as religious practice to escape legal sanction." ${ }^{109}$

It is too early to know whether the decision in Hobby Lobby will prove to be as exotic as these limitations suggest or will come to be seen as the camel's nose under the tent. The limitation to race discrimination as the barrier against pretext is deeply disturbing at best. The excess significance of sexuality in the construction of definitions of morality should not so easily lead to a different result than in race-related cases.

\section{B. Voice, Not Exit}

The second principle that should guide courts in culturally volatile cases such as GRC builds on the first. If obeying a generally applicable law does not communicate a message, an objecting individual has two options. The first option is voice; the second is exit. In adjudicating such disputes, judges should interpret doctrine and fashion remedies with the goals of fostering voice and discouraging exit.

By voice, I mean that that the individual or entity complying with an antidiscrimination law can actively express its disagreement with the implicit message of such a law-e.g., the message that sexual orientation is a morally neutral characteristic and that discrimination on that basis is wrong. The voice in this situation is the voice of dissent. The second option — exit—can take multiple forms. It may result in civil disobedience or in withdrawal from the activities being regulated, as when Catholic adoption agencies have ceased providing services to government agencies rather than comply with an antidiscrimination law.

In effect, the consequence of treating civil obedience as non-expressive is to allocate the burden of dissent (or exit) onto the civil rights objector. Ironically, the burden and right of dissent, should the party exercise it, constitutes a form of coming out-in this instance coming out as an objector to the antidiscrimination message embodied in a majoritarian law.

\footnotetext{
${ }^{108}$ Id. at 2780-82.

${ }^{109}$ Id. at 2783.
} 
Consider the subtle but important difference that this allocation of burden would have made in GRC. What actually occurred, after the litigation ended, was that the gay student groups agreed to include statements in their publications that the University did not endorse the positive views toward homosexuality that the student group communicated. There is a whiff of shaming in this result. By contrast, had the University stated in relevant materials that it did not endorse the views of the gay student groups (or, more appropriately, of any student groups), the implicit positioning would have signaled that Georgetown was the entity that needed to dissent, that antidiscrimination was the norm. Requiring Georgetown to state its own position would not have disrespected that position, but it would have aligned the remedy with the fact that the D.C. antidiscrimination statute had shifted the baseline norm.

There are other advantages to structuring a remedy that allocates the burden to dissent in this way. It furthers an important goal of pluralist governance, which is to enliven the diversity of viewpoints available in the culture. Rather than suppress opposition to an antidiscrimination mandate, such a remedy facilitates it.

One may object that pressuring an organizational or institutional dissenter to express its views more publicly could have the disadvantage of making internal change slower and more difficult. If an institutional dissenter is forced to dig in its heels and defend its opposition to a civil rights law, the ideological diversity within the group may diminish, leading to less willingness to change. While I acknowledge this risk, it seems to me that a mark of greater respect for the dissenter's position is to allow such change to occur, or not, against the backdrop of greater transparency of the views being espoused.

The compromise result that the GRC court fashioned is understandable, given the appropriate desire to preserve the dignity of both parties. But there is a better and more focused principle than minimalism or pluralism for courts to use as guidance: the goal of fostering voice and discouraging exit.

\section{Protecting Dissent}

The final component of the adjudicatory principles that I offer here can be stated simply: together with a goal of enhancing dissent and discouraging exit

comes the concomitant responsibility of courts to protect the right of dissent to 
which objectors are entitled. When popular opinion is changing, the pressure to conform to suddenly reversed norms can be harsh.

In Okwedy v. Molinari, ${ }^{110}$ for example, the Second Circuit correctly accorded scope for dissent from antidiscrimination norms. In that case, a church had contracted with a commercial vendor of billboard space to display a Bible verse condemning homosexuality in Staten Island, New York. Soon after the billboards were posted, the vendor received a letter from the Borough President stating that the display "conveys an atmosphere of intolerance which is not welcome in our borough ... [P]lease contact ... my legal counsel ... to discuss further the issues I have raised in this letter." 111 The vendor removed the signs.

When the church and its pastor sued, the district court dismissed their First Amendment claims on the grounds that the Borough President did not have regulatory authority over the vendor and that his letter merely called for dialogue rather than threatening economic retribution. ${ }^{112}$ The Second Circuit reversed, finding a sufficient basis for inferring threats by a public official, even if not of official power, to require that the claims be reinstated. ${ }^{113}$

A situation such as the use of public billboards presents the easiest case for recognizing the importance of the First Amendment rights of those who oppose LGBT equality, because it raises no problems of captive or susceptible audiences or the potential for workplace disruption. Even in situations in which those other concerns are present, however, courts need to exercise special care to ensure that enforcement of antidiscrimination laws and norms does not silence the voices of those who disagree.

In Good News Employee Association v. Hicks, members of an employee group posted notices in the workplace describing the organization as "a forum for people of Faith to express their views on .... the Natural Family, Marriage and Family values [sic].” ${ }^{114}$ The employer, a public agency, removed the flyers on the ground that the language was homophobic and could promote harassment based on sexual orientation, a result upheld by the trial and appellate courts. The district court acknowledged that this was a close case: on the one hand, the employer had

\footnotetext{
110333 F.3d 339 (2d Cir. 2003).

$111 \mathrm{Id}$. at 342.

112 Okwedy v. Molinari, 150 F. Supp.2d 508, 518 (E.D.N.Y. 2001).

113333 F.3d at 343.

${ }^{114} 2005$ WL 351743 at *1 (N.D. Cal. Feb. 14, 2005), aff'd, 223 Fed. App’x 734 (9th Cir. 2007).
} 
an independent right to prevent disruption in the workplace and there had been a complaint; on the other hand, the language was not inflammatory and only one complaint had been filed. ${ }^{115}$ On balance, the court found that group had only a de minimis protectable right to post messages when regulation of the system properly lay in the employer's discretion.

In my view, this was too narrow a view of the rights of the conservative employees' group. The language of its flyer was too mild, and the principle of protecting dissent too important, to justify the removal. Although the context was a workplace, where other employees are to some extent a captive audience, a flyer on a bulletin board is not difficult to ignore, and there was no evidence that the group's message was targeted to specific individuals.

The school T-shirt cases present the most difficult situations to assess, because the context involves minors and schools' appropriate desire to insulate them from messages that might impair the learning environment even without causing measurable disruption. There is no easy way to distinguish between "homosexuality is shameful," 116 "straight pride," 117 and "be happy, not gay."118 As Judge Posner noted, derogatory comments about "a sexual orientation that deviates from the norm . . . can strike a person at the core of his being [, especially] adolescent students." 119 On that basis, one can distinguish reasonable policies by school officials that suppress speech that, in a different context, would be entitled to First Amendment protection.

\section{Summary}

In sum, this Part argues for an alternative to supplement the privileging of judicial minimalism as a mechanism for enhancing cultural pluralism. A threepart set of interpretive devices-treating civil obedience as non-expressive, allocating the burden of dissent from the message of antidiscrimination laws to

\footnotetext{
1152005 WL 351743 at *2-9.

116 Harper ex rel. Harper v. Poway Unified Sch. Dist., 345 F. Supp. 2d 1096, 1100 (S.D. Cal. 2004), aff'd, 445 F.3d 1166 (9th Cir. 2006), reh'g denied, 455 F.3d 1052 (9th Cir. 2006) (en banc).

117 Chambers v. Babbitt, 145 F. Supp. 2d 1068, 1070 (D. Minn. 2001).

118 Nuxoll v. Indian Prairie Sch. Dist., 523 F.3d 668, 670 (7th Cir. 2008).

${ }^{119}$ See id. at 671.
} 
those who object to those laws, and stringently protecting those rights to dissentwill preserve dignity rights on both sides while better aligning with the goal of achieving equality. These interpretive principles should form part of pluralist jurisprudence.

\section{Civil Rights Moralism}

Because both sexuality and religious liberty are so morally charged, so intrinsically infused with normative constructs, disputes in which the two sets of rights are pitted against each other are especially revealing of fissures in the meaning of antidiscrimination law. On one hand, this branch of law is treated as a viewpoint-neutral regulatory mechanism for equalizing opportunity in economic markets and civil society. On the other hand, more informally but with comparable frequency, courts describe antidiscrimination law in openly expressive and specifically moralistic terms. When antidiscrimination law covers a form of stigmatized sexuality, the two cultural meanings of this type of law clash, sometimes in rhetorically violent terms.

The idea of racial equality has become a core principle in the American narrative of progress, embedded alongside the belief that whatever can be correctly categorized as racist behavior is intrinsically morally wrong. The origins of what I would call civil rights moralism are understandable, and even noble.

The civil rights movement for racial equality, especially as it emerged in the South, steadfastly linked itself to a broadly envisioned concept of Christian ethics, amplified by the prophetic traditions within African-American Protestantism. Invoking "the Supreme Court, the Constitution, and God Almighty" as a seamless conjoined authority created a powerful message for the movement both externally and internally. ${ }^{120}$ The gestalt of civil rights organizing was "a part of the historical tradition of religious revivals as much as it [was] of the tradition of protest movements." "121

\footnotetext{
120 See, e.g., Martin Luther King, Jr., Address to the Montgomery Improvement Association (Dec. 5, 1955) (transcript available at http://mlkkpp01.stanford.edu/index.php/encyclopedia/documentsentry/mia_mass_meeting_at_holt_street_ba ptist_church/) ("If we are wrong, the Supreme Court of this nation is wrong. If we are wrong, the Constitution of the United States is wrong. And if we are wrong, God Almighty is wrong.”).

121 David L. Chappell, A Stone of Hope: Prophetic Religion and the DeAth of Jim CROW 87 (2004).
} 
Throughout the 1950s, movement leaders prioritized securing a presidential imprimatur for an explicitly moral framing of the issue. ${ }^{122}$ When President Kennedy declared in 1963 that the question of integration forced the nation to confront "a moral issue ... . [that] is as old as the Scriptures and . . . as clear as the American Constitution," movement leaders celebrated the speech as an enormous breakthrough, not only in their public statements but in their private communications as well. ${ }^{123}$

Yet that framing leads directly to its own reaction. Religious conservatives argue that a sincere belief in the moral evil of homosexuality could not possibly constitute a civil rights violation in a universe of meanings in which a violation of civil rights is itself morally wrong. To the observant adherent of traditionalist conservative Christianity or the other western faiths, both could not be true. ${ }^{124}$ The dilemma of civil rights moralism arises from disbelief that condemnation of evil can encompass both the wrong of bigotry and the wrong of homosexuality.

For some religious conservatives, the possibility that Bob Jones could be applied in a LGBT equality context as the GRC panel did - to forbid a religious institution from engaging in a practice that is core to its faith - leads the parade of horribles to be feared from the acceptance of marriage equality. ${ }^{125}$ The most common rejoinder-that Bob Jones is an outlier decision unlikely to be applied outside the context of race-fails to grapple with what a future court could plausibly do. ${ }^{126}$

122 See TAylor Branch, Parting the Waters: America in the King Years 1954-1963 213 (1988); DAVID J. GARROW, BEARING THE CROSS: MARTIN LutHER KING, JR. AND THE SOUTHERN CHRISTIAN LEADERSHIP CONFERENCE 119 (1986).

123 BRANCH, supra note 125, at 823-24; GARROW, supra note 125, at 269.

124 See, e.g., Chai R. Feldblum, The Moral Rhetoric of Legislation, 72 N.Y.U. L. REV. 992, 9971007 (1997); Peter M. Cicchino et al., Comment: Sex, Lies and Civil Rights: A Critical History of the Massachusetts Gay Civil Rights Bill, 26 HARV. C.R.-C.L. L. ReV. 549, 611-15 (1991); Developments in the Law - Employment Discrimination, 109 HARV. L. REV. 1568, 1628-29 (1996) (describing state laws prohibiting discrimination based on sexual orientation that also specifically disavowed legislative condoning of homosexuality).

125 Ross Douthat, Op-Ed., The Terms of Our Surrender, N.Y. TIMES, Mar. 2, 2014, at SR12.

126 Martha C. Nussbaum, LiBerty of Conscience: In DEFENSE of AMERICA's Tradition of RELIGIOUS EQUALITY 339 (2010) (denial of tax exemption because of sexual orientation discrimination would be "unthinkable"). For an argument that Bob Jones should be extended to cover discrimination against women, see Caroline Mala Corbin, Expanding the Bob Jones 
In the LGBT equality cases that have come before the Supreme Court, Justice Scalia's opinions epitomize both the morality-inflected arguments at issue in these disputes and the emotional defensiveness that they trigger. The foundational premise of his opinions is the refusal to accept the equivalence of sexual orientation discrimination and race discrimination, reasoning that the latter is properly aligned with bigotry, while the former represents healthy majoritarian interpretations of morality.

In the first of a series of dissenting opinions in LGBT equality cases, Justice Scalia nailed the point: whether "the proposition that opposition to homosexuality is as reprehensible as racial or religious bias" is "precisely the cultural debate" that arises in disputes over LGBT equality laws. ${ }^{127}$ He rejected the majority's ruling that a provision of the Colorado state constitution adopted by voters reflected animus toward lesbians, bisexuals, and gay men, as if "“animosity' toward homosexuality is evil” or "somehow un-American." ${ }^{128}$ In his view, Colorado's anti-gay law reflected merely a different form of morality, not an inferior form. To Justice Scalia, support for a discriminatory law rested on the time-honored belief that "homosexuality is morally wrong and socially harmful" and on merit worthy efforts to defend "traditional American moral values" ${ }^{129}$ and "prevent piecemeal deterioration of majoritarian sexual morality."130

Justice Scalia's dissent in United States v. Windsor ${ }^{131}$ uses language even more saturated with alarm over losing a claim to the moralist high ground. At issue in Windsor was a constitutional challenge to the Defense of Marriage Act (DOMA), which forbade the federal government from recognizing lawful samesex marriages. Scalia chastised the majority opinion for celebrating "how superior the majority's moral judgment in favor of same-sex marriage is to Congress's 'hateful' moral judgment against it." 132 He railed against the ways in which Justice Kennedy's opinion for the Court found a “'bare desire to harm”” or

Compromise, in Legal Responses to Religious Practices in the United States : ACCOMMODATION AND ITS LEgAL LiMITS 123 (Austin Sarat ed., 2012).

${ }^{127}$ Romer v. Evans, 517 U.S. 620, 636 (1996) (Scalia, J., dissenting) (emphasis removed).

${ }^{128} \mathrm{Id}$. at 643,644 (internal citations omitted).

${ }^{129} \mathrm{Id}$. at 645,651 .

${ }^{130} \mathrm{Id}$. at 653 .

131133 S.Ct. 2675 (2013).

${ }^{132}$ Id. at 2709. 
"malice” toward same-sex couples in DOMA's legislative history. ${ }^{133}$ The primary thread of his dissent is that those who oppose homosexuality or marriage equality are morally good persons holding morally legitimate views, and not the caricatures he accused the majority of suggesting: "those with hateful hearts," 134 "unhinged monsters of a wild-eyed lynch mob,"135 "enemies of the human race" 136 and "of human decency," 137 and, simply, "monsters." 138 Justice Scalia returned to what he had identified in Romer as the heart of a civil rights claim: whether the law's differential treatment was based on a morally unworthy prejudice, equivalent to racial or religious bias.

Justice Scalia's emotionalism and hyperbole may seem extreme, but he is not alone. Some scholars have endorsed his interpretation. ${ }^{139}$ These critics are on target in recognizing that the $j$ 'accuse effect of antidiscrimination claims itself constitutes a significant source of cultural power. Understandably, civil rights advocates may resist any weakening of this significant cultural tool. But, just as it is often difficult in the United States to disaggregate religious teachings from nonsectarian ethical values in the context of sex, it is challenging-but necessary-to distinguish moralism from the social goods and norms embedded in the equality principle.

Consistent with the principle that civil obedience must be interpreted as neutrality under the law, courts faced with normative disputes in civil rights cases should resist the temptation to engage in moralistic reasoning. Revisiting and revising the cultural discourse of antidiscrimination law is important for at least three reasons. First, to do so would lower the intensity of various cultural divisions and thus contribute to a sense of social cohesion. Second, subtracting

\footnotetext{
133 Id. at 2707-09.

${ }^{134}$ Id. at 2707.

${ }^{135}$ Id. at 2708.

${ }^{136}$ Id. at 2709 .

${ }^{137}$ Id. at 2710.

${ }^{138}$ Id. at 2711.

${ }^{139}$ See generally Michael J. Perry, David C. Baum Memorial Lecture: Why Excluding Same-Sex Couples from Civil Marriage Violates the Constitutional Law of the United States (Emory Univ. Sch. of Law Legal Studies Research Paper Series No. 14-269, 2013), available at http://ssrn.com/abstract=2352516; Steven D. Smith, The Jurisprudence of Denigration (Univ. of San Diego Legal Studies Research Paper Series No. 14-143, 2014), available at http://ssrn.com/abstract=2407244.
} 
religious moralism from civil rights arguments would benefit those whose equality claims are most likely to encounter resistance from traditional religious spheres, especially women and sexual minorities. ${ }^{140}$ Ironically, unless antidiscrimination is viewed as more of a transactional mandate and less of a moralistic command, it will continue its position as the legal glove that does not fit for sex and gender claims. Lastly, the search for individual animus has contributed to rendering antidiscrimination law as less useful for attacking structural hierarchies rather than episodic bad actors. Substituting a robust conceptualization of structural discrimination for the search for individual animus would strengthen, rather than weaken, the ethical foundations of a commitment to civil rights.

\section{Pluralisms}

Some disputes strain the capacity of law to produce reasoned conclusions. There is a widespread belief that pluralism is the best response. When society is sharply divided over what constitutes moral goods, the legal system ideally serves to maintain social order and facilitate social integration, performing an essential defensive function in the face of culture wars. Concepts of pluralism furnish the lodestar for that effort. With that safety valve in place, modern liberal democracies can encourage creative tension among the state, civil society and religious institutions as generators of moral values and beliefs. The trick is to maintain the magic mixture of competition and harmony, an equilibrium that will protect minority views and values from destruction if not extinction.

The normative punch of pluralism lies in its ethical imperative to respect competing viewpoints and to recognize that incompatible values may be held by persons presumed by the law to be equally rational. The Religion Clauses represent the response of the Framers to this tension: a prohibition on the state from "sending a message to non-adherents that they are outsiders, not full members of the political community, and an accompanying message to adherents that they are insiders, favored members of the political community."141

\footnotetext{
${ }^{140}$ Martha Minow, Should Religious Groups Be Exempt from Civil Rights Laws?, 48 B.C. L. REV. 781, 782 (2007).

${ }^{141}$ Lynch v. Donnelly, 465 U.S. 668, 688 (1984) (O’Connor, J., concurring).
} 
What pluralism is to governance, tolerance is to culture. Tolerance, many believe, offers a repository of universal and neutral values that can be marshaled as aids in the peaceful adjudication of competing moral claims. Law as its own cultural realm has generated principles of adjudication that embody tolerance and pluralism, chief among them the techniques of judicial restraint. The great appeal of minimalism as a pluralism-driven technique for adjudication-of "leaving things undecided" - is its facilitation of more time and cultural space for the informal evolution of views on divisive questions.

Yet the shortcomings of pluralism and tolerance are also wellrehearsed. ${ }^{142}$ While protecting a stigmatized minority from violence (either juridical or physical), reliance on tolerance as an approach to social conflict simultaneously reinforces the status quo of hierarchical power relationships. The more powerful group need only tolerate the less powerful, and the latter group must make do as best it can with something less than equality or redress. A regime of tolerance acts as a kind of mandate for formal equality, but nothing more, in the allocation of access to discursive space.

Judge Mack's opinion in GRC exemplifies cultural tolerance and pluralistic judging. Its genius was the defusing of two seemingly irreconcilable conscience-based positions, framed as the conflict between equality and religious expression. The court succeeded in enforcing the D.C. Human Rights Law while simultaneously treating the claims of the two opposing norm-driven entities as equally entitled to respect. In so doing, it successfully shifted the shape of the dispute from narrow and deep to narrow and shallow, deploying a jurisprudence of minimalism in the service of the politics of pluralism.

The decision has served well as a bridge from a time in which only a tiny fraction of jurisdictions permitted an antidiscrimination claim based on sexual orientation to the present. Its compromise resolution was useful in warding off premature closure of a values debate that continues today, and it bought time for public opinion to evolve. Following an initial period of backlash after the decision, ${ }^{143}$ Georgetown has become a leader among Catholic universities in its

\footnotetext{
${ }^{142}$ See generally Wendy BROWn, REgULATING AVERSION: TOLERANCE IN THE AgE OF IDENTITY AND EMPIRE 14-20 (2006); J.M. Balkin, Some Realism About Pluralism: Legal Realist Approaches to the First Amendment, 1990 DUKE L.J. at 393-94.

143 After the University declined to seek Supreme Court review of the en banc court's decision, Congress amended the D. C. Human Rights Act to create an exemption for religious universities
} 
support of openly LGBT students. ${ }^{144}$ It has established an LGBTQ Resource Center on campus, where the annual award for an outstanding graduating law student is named for the individual who led the plaintiff organization in GRC. ${ }^{145}$ Other Catholic universities have begun to provide similar services. ${ }^{146}$

The GRC decision did not, however, produce constitutional clarity on the critical and lingering question of whether the exclusion of certain persons can be justified as necessary for an entity to communicate its own ideas and self-identity. The singular nature of its resolution-the court's split remedy distinguishing between symbolic and material benefits-limited the precedential impact of the decision. No court of last resort since has cited GRC as determinative.

This Part argues that "pluralism" is best understood as a question, not an answer, in the equality versus religious expression debates. The meaning of pluralism lies in the mind of the beholder. To say that fostering pluralism is the wisest governance model for dealing with diametrically opposite, intensely held beliefs only begs the question of which version of pluralism one supports.

I identify two models of pluralism relevant to the context of disputes between equality rights and religious expression rights, distinguished by how each would structure the role of the state. I argue that in a modern democracy, the state must act as the umpire, not merely as a player, in its implementation of pluralist principles. I close by identifying an example of nested pluralism that is hiding in plain sight in the gay rights versus religious expression debate: the changing content of religious beliefs.

from the public accommodations provision under which the Georgetown litigation was brought. D.C. Code § 2-1402.41(3) (2014). See Walsh, supra note 25 at 564-65.

144 Kyle Spencer, A Rainbow Over Catholic Colleges, N.Y. TimES, July 30, 2013, at ED22; Jenna Johnson, Georgetown U. Tries to be Catholic and Gay-Friendly, WASH. PoST, Dec. 11, 2009.

145 LA Gay and Lesbian Center, Graduating Georgetown Law Student Honored with First Lorri L Jean Award for Excellence, May 9, 2012.

146 Cat Zakrzewski, Catholic Colleges Respond to Demand for LGBTQ Resources, USA TODAY, Sept. 3, 2013, In another sign of change, in 2010, the Association of Jesuit Colleges and Universities joined an amicus brief arguing that there was no First Amendment violation caused by prohibitions on sexual orientation discrimination at universities and by open access requirements that all students be eligible to join all recognized student organizations. Brief for Amici Curiae American Council on Education and Thirteen Other Higher Education Organizations in Support of Respondents at 16-31, Christian Legal Soc’y v. Martinez, 2010 WL 942821. 


\section{A. The State as Player}

Beyond the most generic values associated with tolerance, pluralism itself is a contested concept. The decision in GRC, for example, has been both celebrated and condemned in the name of pluralism. ${ }^{147}$ Such conflicting reactions, claiming the same rationale for opposite conclusions, flow from the fact that pluralism - perhaps because of its “mother and apple pie” appeal in a society that craves less political polarization-has been appropriated to mean two very different systems.

Consider the Biblical injunction to "render unto Caesar the things that are Caesar's and unto God the things that are God's." 148 One can read that simple sentence as implying a sequence or priority: one's obligations as a citizen come first and loom largest, but always with the reservation of core conscience-driven duties toward a deity. Or, it can be read as two equivalent commands.

Proponents of the widest scope of Free Exercise protections endorse the second reading. Under this model of pluralism, the state is one contestant among many, proffering one claim among many as a source of moral authority. Like any interest group, the state constitutes one faction, and must itself operate under a rule of mutual tolerance.

Michael McConnell is the leading scholar and advocate of what he calls "the new American philosophy of religious pluralism." 149 His work best exemplifies this privatist claim to pluralism: the argument that citizens owe no more to Caesar than to God, indeed probably a great deal less:

At its very core, the Free Exercise Clause . . . reflected a theological position: that God is sovereign. It also reflected a political theory: that government is a subordinate association . . . To recognize the sovereignty of God is to recognize a plurality of authorities and to impress upon

\footnotetext{
147 See, e.g., Eskridge and Peller, supra note 4; Eskridge, supra note 4; Walsh, supra note 25, at 561.

148 Matthew 22:21.

149 Michael W. McConnell, The Origins and Historical Understanding of Free Exercise of Religion, 103 HARV. L. REV. 1409, 1513 (1990).
} 
government the need for humility and restraint ... [T] he government has an obligation to defer, where possible, to the dictates of religious conscience . . 150

Another related component of the state-as-player model is an understanding that religious commandments are equivalent to secular laws: "The Free Exercise Clause does not protect autonomy; it protects obligation...The Free Exercise Clause does not protect the freedom of self-determination ... ; it does protect the freedom to act in accordance with the dictates of religion, as the believer understands them.” 151

On this understanding, God is sovereign, the individual is a subject of God, and the state poses a dangerous threat to the individual's ability to carry out her religious duties. A "pluralistic republic" exists when "citizens are free to exercise their religious differences without hindrance from the state." 152 The "pluralistic philosophy of the Religion Clauses" mandates that "the state must create exceptions to laws of general applicability when these laws threaten the religious convictions or practices of religious institutions or individuals." ${ }^{153}$ Institutions of state power - such as courts and legislatures - should create carveouts that can sustain the principle of equal moral authority on as many political and social issues as possible.

To adherents of the state-as-player model, the remedy that Georgetown won in GRC-merely the discretion to withhold what could be perceived as endorsement of the gay student group-constituted a defeat for religious autonomy. Indeed, this particular resolution of the case had been acceptable to the plaintiffs from the beginning of the lawsuit. ${ }^{154}$ Moreover, the role of the statewith its compelling interest in eliminating sexual orientation discriminationoccupied too much normative space.

150 Michael W. McConnell, Free Exercise Revisionism and the Smith Decision, 57 U. CHI. L. REV. 1109, 1152 (1990).

${ }^{151}$ Michael W. McConnell, Religious Freedom at a Crossroads, 59 U. CHI. L. REv. 115, 173-75 (1992) (emphasis in original).

152 Id. at 168.

${ }^{153}$ Id. at 194.

154 In 1979, lawyers for the gay student group suggested that the University issue a public statement declaring that recognition did not constitute endorsement, in order to rebut any implications to the contrary. See 536 A.2d 1, 12 (D.C. 1987). 
If the state is merely one contestant, it then makes perfect sense that antidiscrimination laws that make sexual orientation a protected characteristic would themselves amount to discrimination. Their enforcement creates a burden that has a disparate impact on religious entities that oppose equal treatment based on sexual orientation. This, then, is the pluralist attack on the GRC court's pluralism.

\section{B. The State as Umpire}

The second model of pluralism casts the state as umpire, the incontestable and final source of authority in a constitutional democracy. Protection for religious freedom flows from the mandate on the state to remain neutral as between religions and between religion and non-religion. Debates over what constitutes genuine neutrality center on the scope of the Establishment Clause: if the neutrality principle forces the government to dispense aid, for example, to religious institutions to the same extent as to sectarian institutions, it then runs up against the principle forbidding the advancement of and entanglement with religion. ${ }^{155}$

There is some truth to the criticism that in state-as-umpire pluralism, the implicit foundation is that of secular dominance, since the state is a secular force. Benjamin Berger has characterized the conflict between law and religion as a cross-cultural encounter, and argued "law always vindicates its own cultural understandings." 156 Ultimately, any tolerance is by the state, of religion. For the state-as-umpire model, this reality is not only inevitable, but appropriate. The process of weighing and then comparing the level of harm to different groups from a particular policy, after all, requires someone to determine and enforce the result.

This second model, with which I agree, is grounded in the belief that achieving any common ground in a cosmopolitan modern state requires a "secular public moral order." 157 Pluralist democracy, as William Eskridge has noted, is

155 For example, the debate between the majority and the dissent in Rosenberger, 515 U.S. 819 (1995).

156 Benjamin L. Berger, The Cultural Limits of Legal Tolerance, in AFTER PLURALISM: Reimagining Religious Engagement 99, 108 (Courtney Bender and Pamela Edith Klassen ed., 2010).

${ }^{157}$ Kathleen M. Sullivan, Religion and Liberal Democracy, 59 U. CHI. L. REv. 195, 198 (1992). 
fragile both because its viability is contingent on agreement among diverse and adversarial groups to abide by the processes of law and because the number of identity groups-and thus the level of intensity of inter-group conflict-is constantly increasing. ${ }^{158}$

Where the first model of pluralism would privilege private individual practices and understandings, the state-as-umpire second model is intrinsically committed to a public culture of much broader scope. It shrinks the space for carve-outs from generally applicable laws to that which captures infringements that are not justifiable because of the disproportionality of the harm that they impose as compared to the benefit that accrues from universal enforcement. Certainly Bob Jones would have been decided differently had the first model of pluralism been the Court's operative philosophy.

In addition, situations such as that in GRC when an accommodationist exemption would deny rights or benefits to a third party require a state-as-umpire model in order to protect the status and material well-being of non-adherents.

State-as-player model pluralism, however, is on the offensive, at least in the Supreme Court. The Court's recent opinions concerning the scope of the ministerial exception to antidiscrimination liability ${ }^{159}$ and the viability of a RFRA claim by some for-profit corporations ${ }^{160}$ hint of an opening for the first model in its language suggesting autonomy from generally applicable laws for religious entities, although the holding was explicitly cabined to the facts of that case. Insofar as the issue of LGBT rights is concerned, these two models are well underway on a collision course that began with the decision in GRC.

\section{We Are All Pluralists Now}

What does the future hold? The LGBT equality versus religious liberty conflict will, increasingly likely, become one of the primary sites in which broad understandings of pluralism will be negotiated. As iterative resolutions of this conflict emerge, there will be recalibration of which sexual and religious norms are socially legible as majoritarian or dissenting, and which conceptions of

158 William N. Eskridge, Jr., Pluralism and Distrust: How Courts Can Support Democracy by Lowering the Stakes of Politics, 114 YALE L. J. 1279, 1294-95 (2005).

159 Hosanna-Tabor Evangelical Lutheran Church and Sch. v. EEOC, 132 S. Ct. 694 (2012).

${ }^{160}$ Burwell v. Hobby Lobby Stores, Inc., 134 S. Ct. 2751 (2014). 
morality will acquire greater or lesser cultural power. The role of religion in regulating sexuality has long been so central to its social function that the prospect of that role diminishing calls into question the defining aspects of religious authority in the United States.

With public opinion rapidly shifting on the acceptability of marriage equality and other areas of LGBT equality, it is a safe bet that the social meaning of homosexuality will continue to change. But these will not be the only beliefs that will change. Religious beliefs are also social constructions, which themselves change and will continue to do so. ${ }^{161}$ It is a mistake to see public opinion regarding sexuality as the variable with religious belief as a constant. In fact, both are in motion.

\section{CONCLUSION}

In GRC, the D.C. Court of Appeals understood that its role was not to pick one moral vision over another, but to divide a realm of expressive space. Although the court declared that one side won the battle of symbols and the other side won the battle of material benefits, the question was always whether both would be forced to co-exist in the particular community of meanings that was Georgetown University. The ruling forced that co-existence, which was its greatest achievement.

In this article, I have probed the weaknesses of the decision and used my analysis as the platform for proposing changes enabling courts to better adjudicate disputes that arise at the point of conflict between LGBT equality claims and defenses based on religious expression. I have opposed those who seek a general right of exemption from antidiscrimination laws, but also suggested methods that will enhance the protections for dissent by those who oppose such laws. As these questions continue to arise, which they will, there are many lessons to be learned from the Georgetown case.

\footnotetext{
161 See, e.g., Ahoura Afshar, The Anti-gay Rights Movement in the United States: The Framing of Religion, 3 Essex Hum. RTS. ReV. 64 (2006); Jane Dailey, Sex, Segregation and the Sacred After Brown, 91 J. AMER. History 119, 144 (2004); William N. Eskridge Jr., Noah's Curse: How Religion Often Conflates Status, Belief, and Conduct to Resist Antidiscrimination Norms, 45 GA. L. REV. 657 (2011).
} 